NBER WORKING PAPER SERIES

\title{
THE EFFECT OF RISK ON INTEREST RATES: \\ A SYNTHESIS OF THE MACROECONOMIC \\ AND FINANCIAL VIEWS
}

Pentti J. K. Kouri

Working Paper No. $\underline{643}$

\section{NATIONAL BUREAU OF ECONOMIC RESEARCH 1050 Massachusetts Avenue Cambridge MA 02138}

March 1981

I wish to thank Stanley Fischer, Jorge de Macedo and members of Professor Paunio's money workshop at Helsinki University for useful discussions and comments and the Ford Foundation for financial support. The research reported here is part of the NBER's research program in International Studies. Any opinions expressed are those of the author and not those of the National Bureau of Economic Research. 
The Effect of Risk on Interest Rates: A Synthesis of the Macroeconomic and Financial Views

\section{ABSTRACT}

This paper analyzes the effects of real income and price level uncertainty on equilibrium interest rates. It is demonstrated that even if there are no outside nominal assets, the interest rate on nominal bonds contains a risk premium, or as the case may be, a risk discount. The sign, and the magnitude, of the deviation from the Fisher parity depends on the covariance between the purchasing power of money on the one hand and real income on the other.

The second part of the paper extends the model into a model of two countries, two monies and two bonds denominated in these two monies. It is shown, in contrast with statements made in the literature, that the 'efficiency' of international financial markets does not imply equality of expected real interest rates on bonds denominated in different currencies, nor does it imply that the forward exchange rate should be an unbiased predictor of the future spot exchange rate. This is again true even when there are no outside nominal assets in the world economy.

Pentti J.K. Kouri New York University Department of Economics 8 Washington Place, 7 th Floor New York, New York 10003

(212) $598-7048$ 


\section{Introduction}

This paper analyzes the determinants of interest rates on bonds denominated in different currencies, with emphasis on the effects of risk. Part I of the paper develops a simple stochastic monetary model of a closed economy. In that model the payments arrangements are explicitly specified and money is introduced as a medium of exchange. Nominal and indexed bonds serve as stores of value, and choice between them reflects a trade-off between risk and return. Unlike most macroeconomic models developed in the literature, the model explains financial flows between different groups in the private sector. It is assumed that there is a group of "borrowers" whose income is in the future, and a group of "lenders" whose income is in the present. This difference in endowments explains the existence of a capital market. A further difference between lenders and borrowers is that the borrowers' future real income is uncertain while the income of the lenders is known with certainty. To the extent that the future price level is correlated with real income, borrowers can share their income risk by issuing (or purchasing) nominal bonds. It is shown that this correlation explains the existence of a risk premium or a risk discount on nominal bonds even when the outside supply of nominal bonds is zero. It is shown further that a change in the mixture of bonds supplied by the government between nominal bonds on the one hand, and indexed bonds on the other, changes the risk premium (or discount) on nominal bonds. These results show that the existence of a risk premium in the bond market is fully consistent with all the assumptions that are typically made in the models of efficient capital markets. Thus the Fisher parity is not an implication of market efficiency. 
In the concluding part of section I, I reinterpret the model as one of an open economy, with the indexed bond interpreted then as a foreign currency denominated bond. The model implies that the international Fisher parity does not hold in general but there is typically either a risk premium or a risk discount on the domestic bond. Since the nominal interest rate differential is equal to the forward premium by arbitrage, this result implies that the forward exchange rate is not an unbiased predictor of the future spot exchange rate.

In part II, I develop a model of two countries, two currencies and bonds denominated in these two currencies. The results of this model show that equilibrium interest rates are affected by price level and real income uncertainty in a systematic way.

The analysis of the paper lends support to the macroeconomic portfolio balance models that assume imperfect substitutability, and casts doubt on the extreme "financial views" which assume equality of expected real interest rates with no allowance for systemic changes in risk premia.

The problems addressed in this paper have been earlier discussed in Kouri(1976). That paper developed an international capital asset pricing model with monies, bonds and equities, and demonstrated the existence of risk premia on nominal bonds in market equilibrium. The present paper differs from the earlier paper in its explicit treatment of money as a medium of exchange. Financial flows within the private sector are also modelled explicitly, unlike in the earlier paper which treats the private sector as one entity, Yet another difference is that in this paper I use period analysis rather than continuous time analysis and thus avoid the stock-flow dichotomy that characterizes continuous time portfolio models. Other relevant references include the pioneering contribution of Solnik(1973), and the 
contributions of Grauer, Litzenberger, and Stehle(1976), Fama and Farber(1979), Franke1(1979), de Macedo(1980), Kouri(1976), Kouri and de Macedo(1978), Porter(1971) and Wihlborg(1978). The way that money is introduced in the model is similar to the modelling of money by Clower(1967), Helpman(1979), Lucas (1980), Niehans(1978), and Shubik and Wilson(1977).

Finally a point of clarification. Exchange rate risk is interpreted in this paper literally as unpredictability of the nominal exchange rate, rather than as relative price uncertainty. Indeed, relative prices are assumed to be constant and the purchasing power parity is assumed to hold. The purchasing power parity does not hold in practice, and unpredictable changes in relative prices are obviously an important concern. Kouri and de Macedo(1978) and de Macedo(1979) investigate the effects of such uncertainty on asset demands. A more complete treatment of the problem remains to be done. It is, however, useful to settle the question what effects price level and exchange rate risk have in the financial markets, before considering the more difficult questions that arise with uncertainty of relative prices,

Another simplification made in the paper, that needs to be dropped in further work, is the assumption of price flexibility and full employment. 
PART I

A Mode1 with One Money

In this section I develop a simple stochastic monetary general equilibrium of an economy with three assets: money, nominal one-period bonds and indexed one-period bonds. The structure of the model is as follows. Time flows continuously but it is divided into intervals by evenly spaced discrete points. All economic 'events' take place at these discrete points. Between them the economy is at stationary equilibrium, with all prices and quantities constant. Production, consumption and trade take place continuously, but their levels are adjusted only at discrete points in time. At these same points in time prices are determined in each market so as to clear supply and demand for the duration of the following period. The demand for money derives from transactions requirements within each period: payments for purchases of consumer goods must be made continuously in cash while income is received in the form of lump sum payments at the beginning of each period. This lack of synchronization between cash payments and cash receipts explains stock demand for money. Transactions between money and bonds within periods are ruled out. Otherwise, the treatment of money in the model is the same as in the Baumol-Tobin model of transactions demand. Money does not serve as a store of value. Nominal and indexed bonds serve this function for savers. Bonds are issued by private borrowers who are able in this way to exchange anticipated future income for current consumption. The government also issues bonds to finance deficit spending. There is no equity market in the model. 
In consequence, uncertainty of future real income cannot be directly traded away. It influences the demands for and the supplies of nominal and indexed bonds. Therefore, market equilibrium interest rates will be affected by real income uncertainty, as well as by price level uncertainty. The price level is determined by the quantity equation. The supply of money controlled by the central bank.

I assume a stationary population with overlapping generations. Each cohort lives for two periods and is divided equally into a group of lenders or savers on the one hand, and a group of borrowers on the other. Savers earn income in the first period, and have to save in order to be able to consume in the second period, Borrowers earn no income in the first period. They have to borrow against their uncertain future income in order to be able to consume in the first period. This difference in the endowments of savers and borrowers explains the existence of a capital market. Capital markets provide also the additional function of risk sharing between borrowers whose future real income is uncertain and savers whose real income is certain. Borrowers can share their real income risk with lenders by issuing nominal bonds if the future price level is negatively correlated with their future real income.

Next, I introduce the notation of the mathematical model. Unfortunately, the notation is quite tedious. 
$Y_{1}^{\ell}=$ real income of the young lender in the first period

$\mathrm{L}=1$ abor input of the young $=1$ abor input of the old

$\tilde{Y}_{2}^{\ell}=\begin{aligned} & \text { stochastic real income of the young borrower in the } \\ & \text { second period }\end{aligned}$

$q=1$ abor productivity

$C_{1}^{l}\left(C_{1}{ }^{b}\right)=$ first period consumption of the young lender (borrower)

$\tilde{\mathrm{C}}_{2}{ }^{\ell}\left(\tilde{\mathrm{C}}_{2}{ }^{\mathrm{b}}\right)=\begin{aligned} & \text { stochastic second period consumption of the young lender } \\ & \text { (borrower) }\end{aligned}$

${ }^{\mathrm{o}} \mathrm{Y}_{1}{ }^{\mathrm{b}}=\mathrm{Y}_{1}{ }^{\ell}=$ real income of the older borrower in period $1=$

${ }^{o} \mathrm{C}_{1}{ }^{l}\left({ }^{\mathrm{b}} \mathrm{C}_{1}{ }^{l}\right)=\begin{aligned} & \text { consumption of the old lender (borrower) in the } \\ & \text { current period }\end{aligned}$

$G=$ government consumption

$Q_{1}=\frac{1}{P_{1}}=\begin{aligned} & \text { purchasing power of money, or the inverse of the price } \\ & \text { level in the first period }\end{aligned}$

$\widetilde{Q}_{2}=\frac{1}{\widetilde{P}_{2}}=$ stochastic pruchasing power of money in the second period

$R_{1}=\begin{aligned} & \text { nominai interest rate on nominal one-period bonds } \\ & \text { in period } 1\end{aligned}$

$r_{1}=$ real interest rate on indexed bonds in period 1

$r_{1}{ }^{n}=\left(1+R_{1}\right) \frac{Q_{2}}{Q_{1}}-1=$ expected real rate of return on one-period nominal bonds

$\bar{Q}_{2}=$ expected purchasing power of money in the second period $A_{1}^{l}\left(A_{1} b\right)=\begin{aligned} & \text { nominal stock of nominal bonds bought or issued by } \\ & \text { young lenders (borrowers) in the first period }\end{aligned}$ 


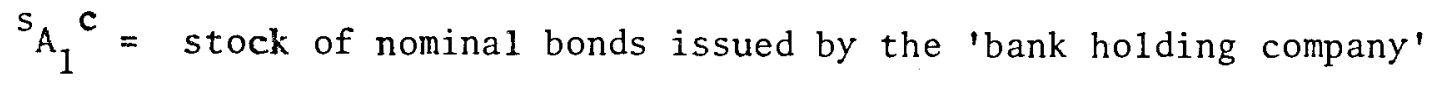
${ }_{-1}^{o} A_{1}{ }^{k}\left({ }_{-1}{ }^{\circ}{ }_{1}^{b}\right)=$ nominal stock of nominal bonds sold or amortized by old lenders (old borrowers) in the first period

${ }_{-1}^{s} A_{1}^{g}=$ stock of nominal bonds issued by the government in the previous period and amortized in the current period

$s_{A_{1}} g=$ stock of nominal bonds issued by the government in the current period

$s_{A_{1}}{ }^{f}=$ stock of nominal bonds issued by firms in the first period

$B_{1}^{j}=$ stock of indexed bonds bought or issued by young lenders $(j=l)$, young borrowers $(j=b)$, or the government $(j=g)$ in the first period

$B_{-1}^{j}=$ stock of indexed bonds bought or amortized by old lenders $(j=2)$, old borrowers $(j=b)$, or the government $(j=g)$

$2 \cdot \mathrm{T}=$ government tax revenue in real terms

$\Pi^{\mathrm{p}}=$ profit of the banking system = seignorage from money creation

$G_{1}=$ government expenditure in the first period $\begin{aligned} M_{1} & = \\ & \text { nominal money stock supplied by the banking system } \\ & \text { in the current period }\end{aligned}$

$M_{1}^{i}=$ nominal money stock held by young lenders $(i=\ell)$, young borrower $(i=b)$, or the government $(i=g)$ at the beginning of the first period

$\mathrm{o}_{\mathrm{M}_{1}}{ }^{\mathbf{i}}=$ nominal money stock held by old lenders $(i=\ell)$ or old borrowers $(i=b)$ at the beginning of the first period $M_{-1}^{f}=\begin{aligned} & \text { nominal money stock held by firms at the end of the } \\ & \text { previous period }\end{aligned}$

$A_{1}^{p}=$ nominal stcck of nominal bonds acquired by the banking system in period 1 
$\tilde{x}$ denotes a stochastic variable

$\overline{\mathrm{X}}$ denotes the expected value of the stochastic variable $\tilde{\mathrm{X}}$

$x$ denotes the realized value of the stochastic variable $\tilde{x}$

$\hat{X}$ denotes the desired or planned value of variable $X$; thus:

$\hat{\bar{x}}_{2}=$ planned expected value of variable $\mathrm{x}$ in the second period $=$ $\bar{x}_{2}=$ expected value of variable $x_{2}$ in the second period; finally, the following two terms will be used:

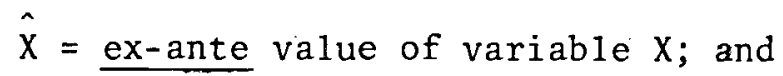

$x=\underline{\text { ex-post }}$ value of variable $x ;$

For notational convenience it is assumed that there is one member in each group. Thus, total population is four.

Before deriving the demand and the supply functions, I discuss the organization of trade and payments. As was said above, prices are changed only at evenly spaced discrete points in time, and they remain constant between 'market days'. All production and consumption plans are also revised only at the same discrete points in time: within market days production and consumption remain constant. After production and consumption plans have been co-ordinated, trade takes place at the equilibrium prices and, by assumption, markets clear continuously until the next market day. Money is needed in the organization of trade between households and firms. At the beginning of each period firms buy labor services from households -at a constant rate per unit of time -- for the duration of the next period. 
Wages are paid as a lump sum payment at the beginning of the period. During the period firms accumulate money balances from the sale of output. Households start the period with a money stock which is equal to their planned consumption expenditure during the period. As they pay for their purchases of consumer goods, they deplete their money balances. At the end of the period, households have no money: the whole money stock is held by firms. The government must also pay continuously for its expenditure with money. I assume that taxes are paid lump sum at the beginning of the period. If taxes were paid continuously the quantity equation would look different. Figure I illustrates the circulation of money in the economy:

\section{Figure I}

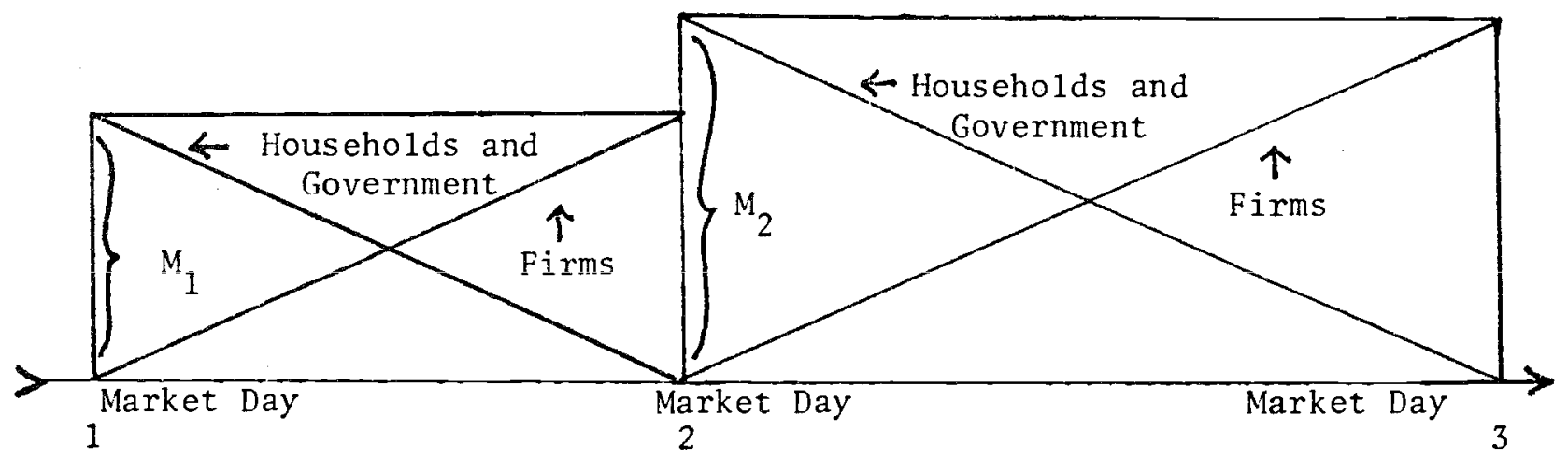

Consider next the conditions of market equilibrium at the beginning of period 1. There are five equilibrium conditions and four markets: output market, labour market, market for nominal bonds, and market for indexed bonds. Equilibrium in the output market during period 1 requires that planned consumption by households and the government equals the planned supply of output by firms. 
1. $\hat{\mathrm{C}}_{1}^{\ell}+\hat{\mathrm{C}}_{1}^{\mathrm{b}}+\mathrm{o}^{\mathrm{O}} \hat{\mathrm{C}}_{1}^{\ell}+{ }^{\mathrm{o}} \hat{\mathrm{C}}_{1}^{\mathrm{b}}+\hat{\mathrm{G}}_{1}=\hat{\mathrm{Y}}_{1}$

Time is measured in such a way that the length of each period is one unit. Thus $\hat{\mathrm{C}}_{1}$, for example, denotes both the rate of consumption at a point in time, as well as the rate of consumption per period:

Output is produced by labor only and full employment is assumed to prevai1. Thus:

$$
\text { 2. } \hat{\mathrm{Y}}_{1}=\mathrm{q}_{1} \cdot 2 \cdot \mathrm{L}
$$

The condition of the labor market equilibrium determines the real wage rate. I assume that firms are competitive and may make zero profit. This requires that:

$$
\begin{aligned}
& \text { 3. } \mathrm{Y}_{1} \cdot \mathrm{P}_{1}=\mathrm{L} \cdot \mathrm{w}_{1}\left(1+\mathrm{R}_{1}\right) \text {, or: } \\
& \text { 4. } \mathrm{w}_{1}=\frac{\mathrm{W}_{1}}{\mathrm{P}_{1}}=\frac{\mathrm{q}_{1}}{1+\mathrm{R}_{1}}
\end{aligned}
$$

The left-hand side of equation (3) is the cumulative value of sales during period 1. It is also equal to the stock of money balances held by firms at the end of period $1 . L \cdot W_{1}$ on the right-hand side is the lump sum wage payment that the firm makes at the beginning of period 1 . This payment is financed by a loan with interest rate $R_{1}$. The condition of zero profit requires that firms are able to pay the principal and the interest of their loans with the money that they have at the end of the period. This is exactly what equation (3) says. Equation (4) shows that the equilibrium real wage rate is a decreasing function of the nominal interest rate. This is because the cost of working capital, or money balances in this case, is the nominal interest rate when money pays no interest. The cost 
of working capital is typically ignored in models of price determination, although it is as real as the costs of any other necessary inputs.

The equilibrium condition for the market for nominal bonds is:

$$
\text { 5. } \quad \hat{A}_{1}^{\ell}+\hat{A}_{1}^{b}-S \hat{A}_{1}^{c}-\hat{A}_{1}^{f}-\hat{A}_{1}^{g}+\hat{A}_{1}^{p}=0 \text {. }
$$

The first three terms are discussed later. Firms need to borrow $\left(\mathrm{A}_{1}{ }^{\mathrm{f}}\right)$ to finance the advance payment of wages. The governments' borrowing requirement $\left({ }^{\mathrm{S}} \mathrm{A}_{1}{ }^{\mathrm{g}}\right)$ arises from deficit spending. The demand for bonds by the banking system, or the supply of bank loans $\left(A_{1}^{p}\right)$ is equa 1 to the supply of money. Note that the equilibrium condition for the bond market is in terms of new issues or new acquisitions. This is because a11 bonds are one-period bonds; there is no 'overhang' from the previous period. Bonds acquired or issued in the previous period do, however, enter the budget constraints.

The market for indexed bonds is in equilibrium when the following equation holds:

$$
\text { 6. } \hat{\mathrm{B}}_{1}^{\ell}+\hat{\mathrm{B}}_{1}^{\mathrm{b}}+\hat{\mathrm{B}}_{1}^{\mathrm{g}}=0 \text {. }
$$

Neither firms nor banks hoid or issue indexed bonds. Both are completely hedged against unpredictable changes in the price level because they only hold nominal assets or liabilities.

The fifth equilibrium condition is that between the demand for and the supply of money:

$$
\text { 7. } \frac{\hat{\mathrm{M}}_{1}^{\ell}}{\mathrm{P}_{1}}+\frac{\hat{\mathrm{M}}_{1}^{\mathrm{b}}}{\mathrm{P}_{1}}+\frac{\mathrm{o}_{\mathrm{M}_{1}^{\ell}}^{\ell}}{\mathrm{P}_{1}}+\frac{\mathrm{o}_{\mathrm{M}_{1}}^{\mathrm{b}}}{\mathrm{P}_{1}}+\frac{\hat{\mathrm{M}}^{\mathrm{g}}}{\mathrm{P}_{1}}=\frac{\mathrm{M}_{1}^{\mathrm{s}}}{\mathrm{P}_{1}} \text {. }
$$


Firms' stock demand for money is zero at the beginning of the period because they make a lump sum payment of the total wage bill. At the end of the period the firms, however, hold the entire money stock initially held by households and the government.

I shall not be concerned with the details of monetary control. I assume simply that the central bank controls the total supply of money, and treat the banking system as a consolidated entity.

Given the level of output from equation (2), only three of equations (1), (5), (6) and (7) are independent by Walras' Law. The three are sufficient to determine the price level $\left(P_{1}\right)$, the nominal interest rate $\left(R_{1}\right)$, and the real rate of interest on indexed bonds $\left(r_{1}\right)$.

Next, I discuss the balance sheet constraints of the economic agents. Since these must hold both in terms of desired and actual values, I do not make the distinction below. For the consolidated banking system we have:

$$
\begin{aligned}
& \text { 8.1. } \Pi_{1}^{\mathrm{P}}=\mathrm{A}_{-1} \mathrm{p} \cdot \mathrm{R}_{-1} \text { and } \\
& \text { 8.2. }{ }_{\mathrm{M}_{1}}^{\mathrm{S}}=\mathrm{A}_{1}^{\mathrm{S}}=
\end{aligned}
$$

The first equation simply states that the profit of the banking system, or the seignorage from money creation, is equal to the total interest income that banks earn on their holdings of nominal bonds. The second equation says that the supply of money in period 1 is equal to the stock of bonds purchased by the banking system in period 1 .

The distribution of the seignorage introduces some complications. The implicit tax on money balances causes distortions which need to be examined more carefully in a separate paper. In this paper I assume that there is a 'holding company' of all banks which distributes the seignorage 
back to wage earners in such a way that their income is not affected by the implicit tax on cash balances. This requires a transfer to wage earners in the amount $\frac{R_{1}}{1+R_{1}} Y_{1}$ which is the present value of the seignorage that accrues to banks in the current period and is available at the end of the period. The holding company has to borrow to be able to make the payment at the beginning of the period:

$$
\text { 9. } \quad \mathrm{s}_{\mathrm{A}_{1}}{ }^{\mathrm{c}}=\frac{1}{1+\mathrm{R}_{1}} \pi_{2}^{\mathrm{p}}=\frac{\mathrm{R}_{1}}{1+\mathrm{R}_{1}} \cdot \mathrm{Y}_{1} \mathrm{P}_{1} \text {. }
$$

The balance sheets of firms have already been discussed in connection with equation (3). They are given more explicitly by the following two equations:

10.1. $\mathrm{M}_{-1}^{\mathrm{f}}=\mathrm{s}_{-1} \mathrm{f}\left(1+\mathrm{R}_{-1}\right)$ and 10.2. $\quad \mathrm{s}_{\mathrm{A}_{1}}{ }^{\mathrm{f}}=2 \mathrm{LW} \mathrm{W}_{1}=\frac{1}{1+\mathrm{R}_{1}} \mathrm{Y}_{1} \mathrm{P}_{1}$.

The first equation says that the stock of money held by firms at the end of the previous period is just sufficient to pay the outstanding loan as we11 as the interest on the loan. According to the second equation, the firms' issue of bonds in the current period is equal to their total wage payment at the beginning of the period.

The budget constraint of the government is given next.

$$
\text { 10.3. } \mathrm{G}_{1}+\left(1+\mathrm{R}_{-1}\right)^{\mathrm{s}} \mathrm{A}_{-1} \mathrm{~g}_{/ \mathrm{P}_{1}}+\left(1+\mathrm{r}_{-1}\right)^{\mathrm{s}} \mathrm{B}_{-1}^{\mathrm{g}}=2 \mathrm{~T}+\mathrm{s}_{1} \mathrm{~g}_{1} \mathrm{P}_{1}+\mathrm{s}_{\mathrm{B}_{1}^{\prime}}^{\mathrm{g}} \text {. }
$$


The left-hand side of this equation is the sum of total government expenditure on goods and services $\left(G_{1}\right)$ and on the service of public debt. The right-hand side shows the two sources of finance: tax revenue (2T) and borrowing $\left(\mathrm{s}_{1}^{\mathrm{g} / \mathrm{P}_{1}}\right.$ and $\left.\mathrm{s}_{\mathrm{B}_{1}}{ }^{\mathrm{g}}\right)$.

For the household sector we need to specify budget constraints for four different groups: young borrowers and lenders, and old borrowers and 1enders.

old lenders spend all of their assets in the second period of their lives:

$$
\text { 11. } \quad{ }^{o} \mathrm{C}_{1}^{\ell}=\left({ }^{o} \mathrm{~A}_{-1}{ }^{\ell} / \mathrm{P}_{1}\right)\left(1+\mathrm{R}_{-1}\right)+{ }^{\mathrm{o}_{\mathrm{B}}}{ }_{-1}^{\ell}\left(1+\mathrm{r}_{-1}\right) \text {. }
$$

old borrowers earn wage income in the current period, and receive one-half of the seignorage. They also pay taxes to the government:

$$
\text { 12. }{ }^{\mathrm{o}} \mathrm{C}_{1}{ }^{l}=\mathrm{Y}_{1}-\mathrm{T}_{1}+\left(1+\mathrm{R}_{-1}\right) \mathrm{A}_{-1}{ }^{\mathrm{b}} / \mathrm{P}_{1}+\left(1+\mathrm{r}_{-1}\right) \mathrm{B}_{-1}^{\mathrm{b}} \text {. }
$$

For young lenders and borrowers we need to specify budget constaints for two periods. Young lenders earn income and pay taxes in the first period. The tax payment is made at the beginning of the period. The budget constaint is:

13. $C_{1}^{\ell}+A_{1}^{\ell} / P_{1}+B_{1}^{\ell}=Y_{1}-T$.

The second period budget constraint is stochastic:

14. $\tilde{C}_{2}^{\ell}=\left(A_{1}^{\ell} / \vec{F}_{2}\right)\left(1+R_{1}\right)+B_{1}^{\ell}\left(1+r_{1}\right)$. 
Young borrowers earn no income in the current period and, accordingly, must borrow to finance their consumption:

15. $\mathrm{C}_{1}^{\mathrm{b}}+\mathrm{A}_{1}^{\mathrm{b} / \mathrm{P}_{1}}+\mathrm{B}_{1}^{\mathrm{b}}=0$.

It is not necessary that both $A^{b}$ and $B^{b}$ are negative, only that their sum is negative.

The second period budget constraint of young borrowers is given by:

16. $\tilde{\mathrm{C}}_{2}^{\mathrm{b}}=\tilde{\mathrm{Y}}_{2}-\mathrm{T}+\left(\mathrm{A}_{1}^{\mathrm{b}} / \tilde{\mathrm{P}}_{2}\right)\left(1+\mathrm{R}_{1}\right)+\mathrm{B}_{1}^{\mathrm{b}}\left(1+\mathrm{r}_{1}\right)$.

The accounting framework of the model is now complete. What remains to be done is to derive the consumption and the asset demand functions.

I assume that the intertemporal and risk preferences of borrowers and lenders are identical. Both seek to maximize expected utility from current and future consumption subject to their budget constraints, specified above. I also assume that the different groups hold the same expectations concerning the future. To obtain explicit results, I assume a quadratic utility function of the form:

17. $\max E_{1} U\left(C_{1}, \tilde{C}_{2}\right)=E_{1}\left\{\frac{1}{2} C_{1}+\frac{1}{2} \tilde{C}_{2}-\frac{1}{2} Y\left(C_{1}-\tilde{C}_{2}\right)^{2}\right\}$, where $E_{1}$ denotes expected value at the beginning of period 1 .

The only parameter, $\gamma$, measures both risk aversion and intertemporal substitution. This can be seen by writing the maximand in the form:

18. $\max \left\{\frac{1}{2} \mathrm{C}_{1}+\frac{1}{2} \overline{\mathrm{C}}_{2}-\frac{1}{2} \gamma\left(\mathrm{C}_{1}-\overline{\mathrm{C}}_{2}\right)^{2}-\frac{1}{2} \mathrm{~V}\left(\tilde{\mathrm{C}}_{2}\right)\right\}$, where $\mathrm{V}\left(\tilde{\mathrm{C}}_{2}\right)=\mathrm{E}_{1}\left(\tilde{\mathrm{C}}_{2}-\overline{\mathrm{C}}_{2}\right)=$ variance of second period consumption. The interpretation 
of this equation is that the agent has equal dislike for variability $\left(\left[\mathrm{C}_{1}-\overline{\mathrm{C}}_{2}\right]^{2}\right)$ and variance $\left(\mathrm{V}\left[\tilde{\mathrm{C}}_{2}\right]\right)$, or unpredictable variability of consumption over time.

At this point it is necessary to specify the stochastic elements of the mode1. I assume that productivity is stochastic and therefore rea1 income is also stochastic. The variance of real income is assumed to be constant and it is denoted by $\sigma_{Y}{ }^{2}$. The other exogeneous source of uncertainty is the uncertainty of the future money supp $1 y$. To save on notation I sha11, however, carry out the analysis directly in terms of price level uncertainty, or rather in terms of the uncertainty of the purchasing power of money (inverse of the price leve1). The variance of the proportionate change in the purchasing power of money $\left(\tilde{Q}_{2} / Q_{1}\right)$ is denoted by $\sigma_{Q}{ }^{2}$. Finally, the covariance between $\Psi_{2}$ and $\left(\mathcal{Q}_{2} / Q_{1}\right)$ is denoted by $\sigma_{Y Q}$.

Consider now the choice problem of the young lender. He seeks to maximize (17), subject to (13) and (14). Upon substitution, the unconstrained maximization problem becomes:

19. $\max \left\{\left\{\frac{1}{2} A_{1}{ }^{\ell} r_{1}{ }^{n}+\frac{1}{2} B_{1}{ }^{\ell} r_{1}-\frac{1}{2} \gamma\left(Y_{1}-T_{-1}-A_{1}{ }^{\ell} Q_{1}\left(2+r_{1}{ }^{n}\right)-B_{1}{ }^{\ell}\left(2+r_{1}\right)\right\}^{2}-\right.\right.$ $\left.\left.\frac{1}{2} \gamma\left(A_{1}{ }^{l} Q_{1}\right)^{2}\left(1+r_{1}{ }^{n}\right)^{2} \sigma_{Q}{ }^{2}\right\}\right\}$, where

$\mathrm{r}_{1}^{\mathrm{n}}=\left(1+\mathrm{R}_{1}\right) \frac{\overline{\mathrm{Q}}_{2}}{\mathrm{Q}_{1}}-1=$ expected real return on nominal bonds, and $\sigma_{Q}{ }^{2}=V\left(\Phi_{2} / \bar{Q}_{2}\right)=$ variance of the purchasing power of money in the second period. The first order conditions are: 
20.1. $\frac{1}{2} \mathrm{r}_{1}{ }^{\mathrm{n}}+\gamma\left\{\mathrm{Y}_{1}-\mathrm{T}-\mathrm{A}_{1}{ }^{\ell} \mathrm{Q}_{1}\left(2+\mathrm{r}_{1}{ }^{\mathrm{n}}\right)-\mathrm{B}_{1}{ }^{\ell}\left(2+\mathrm{r}_{1}\right)\right\}\left(2+\mathrm{r}_{1}{ }^{\mathrm{n}}\right)-$

$$
\gamma A_{1}^{l} Q_{1}\left(1+r_{1}{ }^{n}\right)^{2} \sigma_{Q}^{2}=0 \text {, and }
$$

20.2. $\frac{1}{2} \mathrm{r}_{1}+\gamma\left\{\mathrm{Y}_{1}-\mathrm{T}-\mathrm{A}_{1}{ }^{\ell} \mathrm{Q}_{1}\left(2+\mathrm{r}_{1}{ }^{\mathrm{n}}\right)-\mathrm{B}_{1}{ }^{\ell}(2+\mathrm{r})\right\}(2+\mathrm{r})=0$.

The choice problem of the young borrower is to maximize (17), subject to (15) and (16). The first order conditions are:

21.1. $\frac{1}{2} r_{1}{ }^{n}+\gamma\left\{-\bar{Y}_{2}+T-A_{1}{ }^{b} Q_{1}\left(2+r_{1}{ }^{n}\right)-B_{1}{ }^{l}\left(2+r_{1}\right)\right\}\left(2+r_{1}{ }^{n}\right)-$

$$
\gamma A_{1}{ }^{b} Q_{1}\left(1+r_{1}{ }^{n}\right)^{2} \sigma_{Q}^{2}-\gamma\left(1+r_{1}{ }^{n}\right) \sigma_{Y Q}=0 \text { and }
$$

21.2. $\frac{1}{2} r_{1}+\gamma\left\{-\bar{Y}_{2}+T-A_{1}{ }^{b} Q_{1}\left(2+r_{1}{ }^{n}\right)-B_{1}^{l}\left(2+r_{1}\right)\right\}\left(2+r_{1}\right)=0$.

In both maximization problems the second order conditions are met. Rather than solving the first order conditions in terms of the individual demand functions, I proceed directly to a discussion of market equilibrium.

\section{Market Equilibrium}

It is convenient to analyze the determination of equilibrium prices in terms of asset demands and supplies, dropping the output market. This can be done in a period mode1, in which the stock-flow dichotomy does not arise (on this point see Tobin[1980]). The three assets in the model under consideration are money, nominal bonds and indexed bonds. The corresponding prices are the price level, the nominal interest rate, and the real interest rate on indexed bonds. Instead of the nominal 
interest rate, I carry the analysis in terms of the expected real interest rate on nominal bonds $\left(r_{1}{ }^{n}\right)$ defined as $\left(1+R_{1}\right) \frac{\bar{Q}_{2}}{Q_{1}}-1$. It should be remembered, however, that this variable is not observable. There is a subtle point that has to be discussed with reference to the condition of equilibrium between the demand for, and the supply of, money. Equilibrium condition (7) is in terms of ex-ante demand for money. We know that ex-ante demand for money is equal to the cumulative value of planned expenditure during the current period. In equilibrium, however, planned expenditure equals total output. Accordingly, the ex-post equilibrium condition can be written in a much simpler form -as a Fisherian quantity equation:

22. $\frac{M_{1}{ }^{S}}{\mathrm{P}_{1}}=M_{1}{ }^{s} \cdot Q_{1}=Y_{1}$.

The distinction between ex-ante equilibrium between money demand and money supply on the one hand, and ex-post equilibrium on the other, does not matter when one is only concerned with equilibrium positions.

To analyze the determination of interest rates, I rewrite equations (5) and (6) in the form:

23. $\mathrm{A}_{1}{ }^{\mathrm{l}} \mathrm{Q}_{1}+\mathrm{A}_{1}{ }^{\mathrm{b}} \mathrm{Q}_{1}={ }^{\mathrm{s}} \mathrm{A}_{1} \mathrm{~g}_{\mathrm{Q}_{1}}+{ }^{\mathrm{s}} \mathrm{A}_{1}{ }^{\mathrm{c}} \cdot \mathrm{Q}_{1}+{ }^{\mathrm{s}} \mathrm{A}_{1}+{ }^{\mathrm{s}} \mathrm{A}_{1}{ }^{\mathrm{f}} \cdot \mathrm{Q}_{1}-\mathrm{A}_{1}{ }^{\mathrm{p}} \cdot \mathrm{Q}_{1}$ 24. $\mathrm{B}_{1}^{\ell}+\mathrm{B}_{1}^{\mathrm{b}}=\mathrm{s}_{\mathrm{B}_{1}^{\mathrm{g}}}^{\mathrm{g}}$.

Equation (23) can be further simplified by using the fact that ${ }^{\mathrm{S}} \mathrm{A}_{1}{ }^{\mathrm{C}}+{ }^{\mathrm{s}} \mathrm{A}_{1}{ }^{\mathrm{f}}=\mathrm{A}_{1}{ }^{\mathrm{p}}$ : the banks only supply working capital to firms and, on a net basis, hold neither government bonds nor bonds issued by households. 
Thus, equation (23) becomes:

25. $\mathrm{A}_{1}{ }^{\mathrm{l}} \mathrm{Q}_{1}+\mathrm{A}_{1}{ }^{\mathrm{b}} \mathrm{Q}_{1}={ }^{\mathrm{s}} \mathrm{A}_{1} \mathrm{~g}_{1}$.

After a11 these efforts we have ended with two equations, (24) and (25), which are familiar from the standard portfolio model. The two 1eft-hand sides of these equations are the net private sector asset demands, while the two right-hand sides represent supplies of assets by the government. Note that, in equation (25) the right-hand side is equal to the total stock of government bonds, including bonds that may be held by the banking system.

No Outside Assets

Consider first the case when there are no government bonds, so that both ${ }^{\mathrm{s}_{\mathrm{A}}}{ }_{1}^{\mathrm{g}}$ and $\mathrm{s}_{\mathrm{B}_{1}}^{\mathrm{g}}$ are zero. Adding up equations (20.1) and (21.1) on the one hand, and equations (20.2) and $(21.2)$ on the other, equilibrium conditions (24) and (25) become:

$26.1 \mathrm{r}_{1}{ }^{\mathrm{n}}-\gamma\left(\bar{Y}_{2}-\mathrm{Y}_{1}\right)\left(2+\mathrm{r}_{1}{ }^{\mathrm{n}}\right)-\gamma\left(1+\mathrm{r}_{1}{ }^{\mathrm{n}}\right) \sigma_{Y Q}=0$, and $26.2 \mathrm{r}_{1}-\gamma\left(\bar{Y}_{2}-\mathrm{Y}_{1}\right)\left(2+\mathrm{r}_{1}\right)=0$.

Equation (26.2) shows that the real interest rate on indexed bonds, $r$, depends only on the expected change of real income. ${ }^{1}$ Risk has no effect on it. Substituting from equation (26.2) into (26.1) we get:

27. $r_{1}^{n}-r_{1}=\frac{1}{2} \gamma\left(1+r_{1}^{n}\right)\left(2+r_{1}\right) \sigma_{Y Q}$.

1. This result does not carry over to more general models. 
Thus, whether there is a risk premium or a discount on nominal bonds depends on whether the covariance between real income and the purchasing power of money is positive or negative. The magnitude of the risk premium (or discount) depends also on the size of the corariance term, rather than on the variance of the purchasing power of money. The premium (or discount) is an increasing function of the level of real interest rates and of the degree of risk aversion, as measured by $\gamma$.

If the covariance term is zero, there is no risk premium or discount. In that case, however, there is no intermediation in nominal bonds either: from equations (20) and (21), $A_{1}^{l}$ and $A_{1}{ }^{b}$ are both equal to zero if ${ }^{\sigma} \mathrm{YQ}$ is equal to zero. As long as there is internediation in nominal bonds, both borrowers and lenders are subject to price level uncertainty, and the equilibrium interest rate will also be affected.

\section{The General Case}

In the general case we have the following two equilibrium conditions, obtained by adding up equations (20.1) and (21.1) on the one hand, and equations (20.2) and (21.2), on the other.

$$
\begin{aligned}
& \text { 28.1. } r_{1}^{n}+\gamma\left\{\left(Y_{1}-\bar{Y}_{2}\right)-A_{1}{ }^{g_{1}}\left(2+r_{1}^{n}\right)-B_{1}^{g}\left(2+r_{1}\right)\right\}\left(2+r_{1}^{n}\right)- \\
& \gamma A_{1}{ }^{g} Q_{1}\left(1+r_{1}^{n}\right)^{2} \sigma_{Q}^{2}-\left(1+r_{1}^{n}\right) \sigma_{Y Q}=0 \\
& \text { 28.2. } r_{1}+\gamma\left\{\left(Y_{1}-\bar{Y}_{2}\right)-A_{1} g_{1}\left(2+r_{1}^{n}\right)-B_{1}^{g}\left(2 \div r_{1}\right)\right\}\left(2+r_{1}\right)=0 \text {. }
\end{aligned}
$$

These equations are nonlinear in the two interest rates, and the implied demand functions for outside assets are not monotonic functions of the two interest rates. The ambiguity arises from the fact that the income 
effects of interest rate changes may offset the substitution effects.

Substituting from equation 25.2 into equation 28.1 we get:

29. $\frac{\mathrm{r}_{1}^{\mathrm{n}}-\mathrm{r}_{1}}{2+\mathrm{r}_{1}}=\frac{1}{2} \gamma\left(1+\mathrm{r}_{1}{ }^{\mathrm{n}}\right)^{2} \sigma_{\mathrm{Q}}{ }^{2} \mathrm{Q}_{1} \mathrm{~A}_{1}^{\mathrm{g}}+\frac{1}{2}\left(1+\mathrm{r}_{1}{ }^{\mathrm{n}}\right) \sigma_{Y Q}$.

This equation shows that the risk premium or discount on nominal bonds contains two elements. The first is the compensation for the inflation risk that the private sector is subject to if it has to hold a positive supply of nominal government bonds. The inflation risk premium, or perhaps more appropriately, the price level risk premium, increases with the variance of the price level as well as with the real value of the stock of nominal government debt. Monetary policy can change the risk premium through the effect of price level changes on the real value of government debt. An increase in the nominal supply of money, for example, increases the price level, reduces the real value of nominal government debt, and thus reduces the inflation risk premium on nominal bonds.

The second component of the total risk premium (or discount) could be called the hedge premium or discount. This was already discussed above. Since $\sigma_{Y Q}$ is equal to $\rho_{Y Q} \cdot \sigma_{Y} \sigma_{Q}$, where $\rho_{Y Q}$ is the correlation between $\tilde{Y}_{2}$ and $\mathcal{Q}_{2} / Q_{1}$, an increase in the variance of real income increases the risk premium if the correlation is positive, and reduces it if the correlation is negative. Note that the risk premium depends also on the level of the two interest rates.

I leave the analysis of the full effects of changes in risk as well as in the supplies of government indexed and nonindexed bonds on the two interest rates for another paper. Next, I reinterpret the model as one of an open economy. 
The Open Economy

Suppose that we call the indexed bond a foreign currency bond instead, and assume that the foreign price level is constant. Let us further assume that all goods are internationally traded and that the purchasing power parity holds. Also assume that foreign investors do not hold domestic bonds. Then, equation (29) gives the expected domestic interest rate, $\mathrm{r}_{1} \mathrm{n}$, as a function of the foreign interest rate, $\mathrm{r}_{1}$, the real value of the outside supply of domestic currency denominated bonds as well as the variance of the purchasing power of domestic money and its covariance with domestic real income.

Since the forward premium must be equal to the difference in nominal interest rates by arbitrage, equation (29) implies that the forward premium is not in general an unbiased predictor of the expected change in the exchange rate. There is a systematic bias which consists of a premium for the exchange rate, or inflation risk when there is a positive outside supply of bonds, and of a hedge premium that derives from correlation between real income and the exchange rate.

\section{Part II}

\section{A Model with Two Monies}

In this part I extend the model to two countries and two monies. To simplify the analysis I assume that both countries produce only internationally traded goods whose relative prices remain constant. The purchasing power parity therefore holds in its absolute form. Accordingly, the exchange rate is determined by: 


$$
\text { 30. } \begin{aligned}
\mathrm{e} & =\frac{\mathrm{p}^{\mathrm{A}}}{\mathrm{P}^{\mathrm{B}}}, \text { where } \\
\mathrm{P}^{\mathrm{A}} & =\text { price level of country } \mathrm{A} \text { (home country) } \\
\mathrm{P}^{\mathrm{B}} & =\text { price level of country } \mathrm{B} \\
\mathrm{e} & =\text { domestic currency price of foreign currency }= \\
& \text { the exchange rate. }
\end{aligned}
$$

Domestic and foreign price levels are determined by domestic and foreign quantity equations, as above.

$$
\begin{aligned}
\text { 31. } & \frac{M^{A}}{P^{A}}=M^{A} Q^{A}=2 \cdot Y^{A}, \frac{M^{B}}{P^{B}}=M^{B} Q^{B}=2 \cdot Y^{B} \text { where } \\
M^{A}\left(M^{B}\right) & =\text { domestic (foreign) money supply } \\
2 Y^{A}\left(2 Y^{B}\right) & =\text { domestic (foreign) output } \\
P^{A}\left(P^{B}\right) & =\text { domestic (foreign) price level } \\
Q^{A}\left(Q^{B}\right) & =\frac{1}{P^{A}}\left(\frac{1}{P^{B}}\right)=\text { purchasing power of domestic (foreign) money. }
\end{aligned}
$$

The quantity equation is written in terms of total output of domestic goods and services, rather than in terms of total expenditure by domestic residents on domestic and imported goods. Thus, foreign residents, too, hold domestic money in the amount of their planned expenditure on domestic goods. This specification of the money demand function is not necessarily the best one in view of the way that the international payments system is actually organized. I use it, following the standard practice, to simplify the analysis of the problems that $I$ am primarily interested in.

Uncertainty enters through $\mathrm{M}^{\mathrm{A}}, \mathrm{M}^{\mathrm{B}}$ and $\mathrm{Y}^{\mathrm{A}}$ and $\mathrm{Y}^{\mathrm{B}}$. It is more convenient, however, to carry out the analysis in terms of real income uncertainty and price level uncertainty, or uncertainty of the purchasing power of money. 
The rest of the model is a replica of the model developed in part I: there are two identical models for the two countries. Using the results and insights of that analysis, we can leave out much of the tedious accounting.

I assume that there are no indexed bonds, only bonds denominated in the two currencies. We know from the previous section that equilibrium in the bond markets can be analyzed in terms of net non-bank demand for bonds on the one hand, and outside government supply of bonds on the other. The supplies of bonds by firms and 'bank holding companies' (see section I) cancel out with the demand for bonds by the banking system. Thus, equilibrium in international financial markets obtains when, in addition to equations (29) and (30), the following two conditions hold:

32.1. $\quad A^{a} Q_{A}+A^{b} Q_{A}=A^{s} Q_{A}$

32.2 $\quad B^{a} Q_{B}+B^{b} Q_{B}=B^{S} Q_{B}$, where

$$
\begin{aligned}
A^{a}\left(A^{b}\right)= & \begin{aligned}
\text { demand for domestic currency bonds by domestic } \\
\text { (foreign) non-bank sector }
\end{aligned} \\
B^{a}\left(B^{b}\right)= & \begin{array}{l}
\text { demand for foreign currency bonds by domestic } \\
\text { (foreign) non-bank sector }
\end{array} \\
A^{S}= & \begin{array}{l}
\text { supply of domestic currency bonds by the } \\
\text { (domestic or foreign) government }
\end{array} \\
B^{S}= & \text { supply of foreign currency bonds by the (foreign } \\
& \text { or domestic) government } \\
Q_{A}\left(Q_{B}\right)= & \frac{1}{P_{A}}\left(\frac{1}{P_{B}}\right)=\text { purchasing power of domestic (foreign) }
\end{aligned}
$$

From part I, the asset demand equations are defined implicitly by the following four equations: 
33.1. $\quad r^{A}+\gamma\left\{\left(Y_{1}{ }^{A}-\bar{Y}_{2}{ }^{A}\right)-A^{a} Q^{A}\left(2+r^{A}\right)-B^{a} Q^{B}\left(2+r^{B}\right)\right\}\left(2+r^{A}\right)-$

$$
\gamma A^{a} Q^{A}\left(1+r^{A}\right)^{2} \sigma_{A}^{2}-\gamma B^{a} Q^{B}\left(1+r^{A}\right)\left(1+r^{B}\right) \sigma_{A B}-\gamma\left(1+r^{A}\right) \sigma_{Y A}^{a}=0
$$

33.2. $\quad r^{B}+\gamma\left\{\left(Y_{1}^{A}-\bar{Y}_{2}^{A}\right)-A^{a} Q^{A}\left(2+r^{A}\right)-B^{a} Q^{B}\left(2+r^{B}\right)\right\}\left(2+r^{B}\right)-$

$$
\gamma A^{a} Q^{A}\left(1+r^{A}\right)\left(1+r^{B}\right) \sigma_{A B}-\gamma B^{a} Q^{B} \sigma_{B}{ }^{2}-\gamma\left(1+r^{B}\right) \sigma_{Y B}{ }^{a}=0
$$

34.1. $r^{A}+\gamma\left\{\left(Y_{1}{ }^{B}-\bar{Y}_{2}{ }^{B}\right)-A^{b} Q^{A}\left(2+r^{A}\right)-B^{b} Q^{B}\left(2+r^{B}\right)\right\}\left(2+r^{A}\right)-$

$$
\gamma A^{b} Q^{A}\left(1+r^{A}\right)^{2} \sigma_{A}^{2}-\gamma B^{b} Q^{B}\left(1+r^{A}\right)\left(1+r^{B}\right) \sigma_{A B}-\gamma\left(1+r^{A}\right) \sigma_{Y A}{ }^{b}=0
$$

34.2. $\quad r^{B}+\gamma\left\{\left(Y_{1}{ }^{B}-\bar{Y}_{2}{ }^{B}\right)-A^{b} Q^{A}\left(2+r^{A}\right)-B^{b} Q^{B}\left(2+r^{B}\right)\right\} \cdot\left(2+r^{B}\right)-$

$$
\begin{aligned}
& \gamma A^{b} Q^{A}\left(1+r^{A}\right)\left(1+r^{B}\right) \sigma_{A B}-\gamma B^{b} Q^{B} \sigma_{B}{ }^{2}-\gamma\left(1+r^{B}\right) \sigma_{Y B}{ }^{b}=0 \text {, where } \\
& r^{A}=\left(1+R^{A}\right) \frac{\bar{Q}_{2}^{A}}{Q_{1}^{A}}-1=\begin{array}{l}
\text { expected real interest rate on } \\
\text { domestic bonds }
\end{array} \\
& r^{B}=\left(1+R^{B}\right) \frac{\bar{Q}_{2}^{B}}{Q_{2}}-1=\begin{array}{l}
\text { expected real interest rate on foreign } \\
\text { bonds }
\end{array}
\end{aligned}
$$

$\sigma_{A}^{2}=v\left(\tilde{Q}_{2}^{A} / Q_{1}^{A}\right)$

$\sigma_{B}^{2}=V\left(\tilde{Q}_{2}{ }^{B} / Q_{1}{ }^{B}\right)$

$\sigma_{A B}=\operatorname{Cov}\left(\tilde{Q}_{2}{ }^{A} / Q_{1}{ }^{A}, \tilde{Q}_{2}{ }^{B} / Q_{1}{ }^{B}\right)$

$\sigma_{A Y}{ }^{a}=\operatorname{Cov}\left(\tilde{Y}_{2}{ }^{A}, \tilde{O}_{2}{ }^{A} / Q_{1}{ }^{A}\right)$

$\sigma_{A Y}{ }^{b}=\operatorname{Cov}\left(Y_{2}{ }^{B}, \widetilde{Q}_{2}{ }^{A} / Q_{1}{ }^{A}\right)$

$\sigma_{B Y}{ }^{a}=\operatorname{Cov}\left(\mathcal{Y}_{2}{ }^{A}, \tilde{Q}_{2}{ }^{B} / Q_{1}{ }^{B}\right)$

$\sigma_{B Y}{ }^{b}=\operatorname{Cov}\left(\tilde{Y}_{2}{ }^{B}, \tilde{Q}_{2}{ }^{B} / Q_{1}{ }^{B}\right)$ 
Equations (32), (33) and (34) provide a complete model of interest rate determination in the international financial markets in terms of private sector demands and government supplies. After some manipulations, the equilibrium yield differential can be written as a function of the outside supplies of the two bonds:

$$
\begin{aligned}
& \text { 35. } \quad r^{A}-r^{B}=\frac{1}{4} r A^{g} Q^{A}\left\{\left(1+r^{A}\right)^{2}\left(2+r^{B}\right) \sigma_{A}^{2}-\left(1+r^{A}\right)\left(1+r^{B}\right)\left(2+r^{B}\right) \cdot \sigma_{A B}\right\}- \\
& { }_{4}^{1} r B^{g} Q^{B}\left\{\left(1+r^{B}\right)^{2}\left(2+r^{A}\right) \sigma_{B}^{2}-\left(1+r^{A}\right)\left(1+r^{B}\right)\left(2+r^{B}\right) \cdot \sigma_{A B}\right\}+ \\
& \frac{1}{4} \gamma\left(1+r^{A}\right)\left(2+r^{B}\right) \sigma_{Y A}-\frac{1}{4} \gamma\left(1+r^{B}\right)\left(2+r^{A}\right) \sigma_{Y B} \text {, where } \\
& \sigma_{Y A}=\sigma_{Y A}^{a}-\sigma_{Y A}^{b} \text {, and } \\
& \sigma_{Y B}=\sigma_{Y B}^{a}+\sigma_{Y B}^{b} \text {. }
\end{aligned}
$$

The two interest rates are equal if and only if outside supplies of the two assets are zero and the covariances of the purchasing powers of the two monies with the real incomes of the two countries are zero. In this special case the equilibrium expected real interest rate can be easily solved. It is given by:

$$
\begin{aligned}
& \frac{r}{2+r}=\frac{r^{A}}{2+r}=\frac{r^{B}}{2+r^{B}}=r\left(\bar{Y}_{2}-Y_{1}\right) \text {, where } \\
& Y_{1}=\frac{1}{2}\left(Y_{1}^{A}+Y_{1}{ }^{B}\right)= \begin{array}{l}
\text { average real income of the two } \\
\text { countries in period } 1, \text { and }
\end{array} \\
& \bar{Y}_{2}=\frac{1}{2}\left(\bar{Y}_{2}^{A}+\bar{Y}_{2}{ }^{B}\right)=\begin{array}{l}
\text { expected average real income of } \\
\text { the two countries in period } 2 .
\end{array}
\end{aligned}
$$

In this case risk has no effect on the equilibrium values of the two interest rates. 
The relative riskiness of the two bonds determines, however, the currency composition of international (and also national) financial intermediation. Subtracting equation (33.2) from equation (33.1) we get:

37. $-(1+r)^{2} A^{a}\left(\sigma_{A}^{2}-\sigma_{A B}\right)+(1+r)^{2} B^{a}\left(\sigma_{B}^{2}-\sigma_{A B}\right)=0$.

Therefore, the relative shares of the two currencies in total international financial intermediation are given by:

38. $\frac{A^{a}}{A^{a}+B^{a}}=\frac{\sigma_{B}^{2}-\sigma_{A B}}{\sigma_{A}{ }^{2}+\sigma_{B}{ }^{2}-2 \sigma_{A B}} ; \frac{B^{a}}{A^{a}+B^{a}}=\frac{\sigma_{A}^{2}-\sigma_{A B}}{\sigma_{A}{ }^{2}+\sigma_{B}{ }^{2}-2 \sigma_{A B}}$.

The shares of the two currencies are simply given by the minimum variance portfolio.

Intuitively, the reason why there are no risk premia in the absence of outside assets is that the private sector can adjust the currency composition of their portfolios so as to minimize their risk exposure. When the price levels are not correlated with real incomes the minimum variance portfolio given by equation (36) minimizes the risk exposure of lenders as well as borrowers.

I conclude with the case when there are no outside assets but prices are correlated with real incomes. In that case the equilibrium interest rates are given by:

39.1. $\frac{r^{A}}{2+r^{A}}=r\left(\bar{Y}_{2}-Y_{1}\right)-\frac{1}{2}\left(\frac{1+r^{A}}{2+r^{A}}\right) \cdot \sigma_{Y A}$

39.2. $\frac{r^{B}}{2+r^{B}}=\gamma\left(\bar{Y}_{2}-Y_{1}\right)-\frac{1}{2} \gamma\left(\frac{1+r^{B}}{2+r^{B}}\right) \sigma_{Y B}$. 
In the general case the equilibrium levels of the two interest rates cannot be solved explicitly, although the difference between the two can be inferred from equation (35).

\section{Concluding Remarks}

It has been demonstrated that except in some special cases, interest rates on nominal bonds contain risk premia or risk discounts. There are two reasons for this. One is the existence of outside assets. In order for the private sector to be willing to hold nominal assets whose real value is uncertain it must be compensated for the risk that it assumes. The other reason is correlation between real incomes and price levels. A positive correlation between real income and the purchasing power of a currency introduces a positive hedging premium on that currency. This occurs because those subject to the real income risk will in that case borrow in the currency that is positively correlated with their real income so as to reduce their total risk exposure. This causes the real interest rate of bonds denominated in that currency to increase.

The opposite case is also interesting. Suppose that there is a country where currency increases in value when there is an adverse supply shock or some other disturbance in the world economy. An example might be the pound sterling that 'benefits' from an oil crisis, or the Swiss franc that benefits from a political crisis. Such currencies become vehicles of hedging and, as a result, bonds denominated in these currencies contain a risk discount, or a 'hedging premium'. In an unstable economic economic environment market perceptions concerning the riskiness of assets 
are not likely to remain invariant over time, and, therefore, changes in risk perceptions need to be taken into consideration when explaining interest rate fluctuations in the international money markets.

I have not discussed exchange rate fluctuations explicitly in the model. What investors and lenders are interested in are the purchasing powers of currencies and the relative riskiness of currencies in terms of their purchasing powers. In the model the purchasing power parity was assumed to hold so that there was no problem in defining the purchasing power of a currency. Furthermore, the purchasing power of each currency is the same for every investor. This is no longer true if there are changes in relative prices. In that case the measurement of the real return and its variance depends on the consumption preferences of the investor. Kouri and de Macedo(1978) and de Macedo(1980) take up this problem but a full general equilibrium treatment remains to be done.

I conclude with a conjecture on the welfare implications of price level uncertainty. As long as there is exogeneous real income uncertainty which cannot be traded through equities, for example, stabilization of the price level would not seem optimal. Instead, nominal demand should be stabilized and the price level should be allowed to reflect 'supply' disturbances. In that way nominal bonds could be used by the private sector to optimally share the irreducible risk of real income fluctuations. Stabilization of the price level would deprive them of this possibility.

The same point holds for exchange rates too. Nominal demands in different countries should be stabilized and exchange rates should be allowed to reflect real income fluctuations.' In this way holdings of bonds denominated in different currencies would enable the private sector 
to share the irreducible risks of real income fluctuations. Fixity of exchange rates would reduce the menu of portfolio choice and would increase the total risk exposure of the private sector. Thus, both price level and exchange rate uncertainty may be appropriate as a second best solution to the problem of diversifying real income risks. 


\section{REFERENCES}

Adler, M, and B. Dumas. "Portfolio Choices and the Demand for Forward Exchange," American Economic Review, May 1976.

Clower, R. "A Reconsideration of the Microfoundations of Monetary Theory," Western Economic Journal, Vo1. 4, 1967; pp. 1-9.

Dornbusch, R. and S. Fischer. "Exchange Rates and the Current Account," American Economic Review, December 1980.

Fama, E. and A. Farber. "Money, Banks and Foreign Exchange," American Economic Review, September 1979.

Franke1, J. "The Diversifiability of Exchange Risk," Journal of International Economics, September 1979.

Grauer, F.L.A., R.H. Litzenberger and R.E. Stehle. "Sharing Rules and Equilibrium in an International Capital Market Under Uncertainty," Journal of Financial Economics, June 1976.

Helpman, E. "An Exploration in the Theory of Exchange Rate Regimes," Working Paper No. 79-2, Department of Economics, University of Rochester, January 1979.

Kouri, P. "Intermational Investment and Interest Rate Linkages Under Flexible Exchange Rates," in R.z. Aliber, ed., The Political Economy of Monetary Reform, Cambridge University Press, 1976.

Kouri, P. and J. de Macedo. "Exchange Rates and the International Adjustment Process," Brookings Papers on Economic Activity, No. 2, 1978.

Lucas, R,E., Jr. "Notes on the Efficiency of Exchange Rate Regimes," private lecture notes, dated March 1980.

Niehans, J. The Theory of Money, Johns Hopkins University Press, 1978.

Porter, M.G. "A Theoretical and Empirical Framework for Analyzing the Term Structure of Exchange Rate Expectations," IMF Staff Papers, Vol. XVIII, No. 3, November 1971.

Rodriguez, C, "The Role of Trade Flows in Exchange Rate Determination: A Rational Expectations Approach," Journal of Political Econony, Vo1. 88, No. 6, December 1980.

Rol1, E. and B. Solnik. "A Pure Foreign Exchange Asset Pricing Model," Journal of International Economics, May 1977.

Shubik, M. and C. Wilson. "The Optimun Bankruptcy Rule in a Trading Economy Using Fiat Money," Zeitschrift für Nationalckonomie, 37, 1977; pp. 337-354. Solnik, B. European Capital Markets: Toward a General Theory of International
Investment, Lexington Books, 1973.

Wihlborg, C. Currency Risks in International Financial Mlarkets, Princeton Studies in International Finance, 44, 1978, 